\title{
Standardization of Sustainable Oleo Gum Resin Tapping Technique in Salai (Boswellia serrata Roxb.) from Tropical Dry Deciduous Forest of Chhattisgarh
}

\author{
Nayak Amit Prakash* and R.K. Prajapati \\ ${ }^{2}$ Department of Forestry, Indira Gandhi Agricultural University Raipur, CG, India \\ *Corresponding author
}

\section{Keywords}

Gum tapping, Exudation, Oleo gum resin, Ethephon, Sustainable yield

Article Info

\section{Accepted:}

17 September 2020

Available Online:

10 October 2020

\section{A B S T R A C T}

Boswellia serrata (Salai guggul), is a moderate to large sized branching tree of family Burseraceae, grows in dry mountainous regions of India, Northern Africa and Middle East. Oleo-gum resin of Boswellia serrata called Kundur in Unani system of Medicine is a prime ingredient in modern quality perfumes. The gum is popularly used in Indian Systems of Medicine (Unani, Ayurvedic \& Sidha) since last several centuries it cures various aliment especially rheumatism, Cancer and skin diseases. A field experiment was carried out on sustainable tapping methods conducted for one year to standardize the tapping methods, tapping seasons, chemical concentration. Trees of $80-150 \mathrm{~cm}$ girth (GBH) are selected in natural forest stands of Deopur Forest Range, Balodabazar Forest Division of Chhattisgarh. To obtaining the maximum oleo gum resin from this lesser known species, different tapping techniques have been applied to enhance the gum production without harm to standing trees. The trees of $B$. serrata by use of Mechanical + Chemical treatment tapping technique total quantity of gum produced in two season was highest in summer (2019) by using $\mathrm{H}_{4} 30 \%$ conc. of ethephon the yield was $52.94 \mathrm{~g} /$ tree and in winter (2018) maximum gum was obtained by using $\mathrm{V}_{3} 20 \%$ conc. ethephon the yield was $26.18 \mathrm{~g} /$ tree in winter season. Whereas, in Mechanical tapping techniques maximum gum was obtained by square shape cut method and the yield was $10.82 \mathrm{~g} /$ tree the other two method i.e., $\mathrm{V}$ shape and Hole shape not much effective for sustainable production of gum. The physiochemical properties of exudates oleo gum resin were investigated in the laboratory and was found to be mild acidic in nature with high moisture content of $17.32 \%$ and low ash content of $1 \%$. This technique was found simple, safe and ensure sustainable gum yield, regeneration and survival of the tapped trees, having no deep incision on bole of trees which resulted no mortality with higher gum yield.

\section{Introduction}

Salai gum is obtained from tree called Boswellia serrata which is also known as
Salai guggal, gum olibanum or frankincense tree. It is one of the most important forest products of our country. The genus Boswellia belongs to the family of Bruseraceae and 
extent widely in the dry regions of tropical Africa, Arabia and India. The two most important trees Commiphora and Boswellia, produces gum resins that are of considerable high commercial value as raw materials for various products. The leaves of this tree is imparipinnate, alternate $30-45 \mathrm{~cm}$ long, crowded at the ends of branches, leaflets 17 31, opposite, variable in shape and size. Flowers are small, white in short racemes, and crowded at the ends of branches .Fruits are trigonous, $12 \mathrm{~mm}$ long, drupe, containing three 1-seeded Pyrenees, winged along the margins. Seed are compressed, hard and winged.

Worldwide there are about 18 species of Boswellia which are either shrubs or trees with outer bark often flaking. Out of these, only two species i.e. $B$. serrata and $B$. ovalifoliolata are distributed in India (Arabia, 2005). Two new species (B. bullata and $B$. dioscoridis) were recently identified in Yemen as reported by (Thulin 2001). Out of these, only two species i.e. $B$. serrata and $B$. ovalifoliolata are distributed in India (Arabia, 2005). In India it has a well marked distribution in central India between $16^{0}$ to $31^{0} \mathrm{~N}$ Latitude and $73^{\circ}$ to $86^{\circ} \mathrm{E}$ Longitudes .It is a moderate to large branching tree, found in dry deciduous forests, being common in dry hills throughout India. The tree occurs mainly in Madhya Pradesh, Andhra Pradesh, Odisha, Rajasthan and Gujarat and to a lesser extent in Maharashtra, Uttar Pradesh and in other dry and tropical regions of the country but it is almost absent in the moist regions of Northeast India and Western Ghat region. It is a characteristic species of dry teak forest, Southern dry mixed deciduous forests, dry peninsular Sal forest, northern dry mixed deciduous forest, and the edaphic climax type of the dry deciduous forests (Champion and Seth, 1968). It is present either singly or in pure belts or patches. Naturally the tree is found on the slopes and ridges of hills, as well as on flat terrain.
The tree is resistant to frost and serves as a nurse tree for other species grown in forest. It is a strong light demander and does not tolerate to shade. It is extremely resistant to drought and resists fire better than any other species in its zone of occurrence. It typically grows well on neutral soils above schist, quartzite, and limestone and sandstone gneiss. It produces root suckers, coppices and pollards well. The species has the ability to resist in the poorest and the shallow soils where most of its associates remain stunted. The tree can be found up to $1150 \mathrm{~m}$ in elevation. The gum obtained from this tree commonly known as Salai guggal, gum olibanum or frankincense having constituents: gum: $20-36 \%$, acid resin: $56-65 \%$ and volatile oils: 4-8\%. Besides, the acid resin of Boswellia serrata usually contains $43 \%$ boswellic acids. Additionally the gum has been reported to contain arabinose, galactose, xylose, galacturonic acid and digitoxose (Holmes, 1999).

The extract obtained from this plant known as Shalaki extract. These extracts made into a very fine powder and transformed into a liquid like substances. Its gum is used for multiple health and medicinal benefits as per Ayurvedic system of medicine this extracts is also known for its anti-inflammatory properties and ability to manage inflammatory disorders, reduce arthritis pain and also speed up healing from infections. These extract from this tree has proved to be beneficial in the prevention of loss of cartilage and also found as an effective painkiller. The tree extract are used in many industries such as beverage, cosmetics, spa treatment food and aromatherapy. Commercial tapping of gum and resin is done by blazing, peeling or making deep incision on the bole of tree (Nair, 2000). In case of gum extraction, it is generally observed that excessive injury caused due to unscientific methods of tapping and overexploitation lead to death of trees this is very serious issue. In this experiment we 
are developing sustainable gum tapping techniques without giving any harm to tree.

\section{Materials and Methods}

\section{Study area}

The study was carried out in natural forest stands where Boswellia serrata is available in mixed stand at Compartment no 281 of Deopur Forest Range in Balodabazar Forest Division (Chhattisgarh), the study area reclined between $21^{\circ} 23^{\prime} \mathrm{N}$ Latitude and $82^{\circ}$ 33' E Longitude with an altitude of 319 above Mean seal level. The study was carried out from October 2018 to May 2019. The average rainfall of the district is $974 \mathrm{~mm}$, temperature varies from $16{ }^{0} \mathrm{C}$ in winters to $42{ }^{0} \mathrm{C}$ in summer. Soil found in this region such as heavy clays to shallow loamy, reddish, brown upland graved. The soil comes under a rang series which further subdivided in to KanharDosra and Dosra and soil shows slight acidic or neutral in reaction

\section{Vegetation structure}

This mixed forest has a rich diversity of tree species which are dominated Lagerstroemia lanceolata, Ixora pavetta, Diospyros melanoxylon, Chloroxylon swietenia, Gardenia resinifera and so many other medicinal and aromatic plants and rich in wildlife (Table 1).

\section{Materials and Methods}

The potential gum yielding trees of Boswellia serrata having $80-150 \mathrm{~cm}$ circumference were marked for tapping purpose. The two tapping techniques were tried for extracting of gum: Mechanical tapping techniques and Mechanical + Chemical tapping techniques by using Square shape, V shape and hole shape cut methods and data were collected in two seasons i.e. winter and summer.

\section{Tapping techniques}

\section{Mechanical tapping technique}

Three mechanical cut as Square shape, V shape and Hole shape incision were made on bole at breast height of trees of Boswellia serrata duringWinter2018and Summer 2019 Seasons details of these incision is given below.

In Square shape cut was made both in length and breadth of $8 \mathrm{~cm}$ with the help of carpenter wood Chisel having depth of 1-2 $\mathrm{cm}$ on trees of $80-150 \mathrm{~cm}$ girth class of trees.

In $\mathrm{V}$ shape cut of length $9 \mathrm{~cm}$ and width $3 \mathrm{~cm}$ having depth of $1 \mathrm{~cm}$ depth was made on 80 $150 \mathrm{~cm}$ girth class of trees and confined nearer to breast height with the help of chisel.

In hole shape cut method a cut of $2.5 * 2.5 \mathrm{~cm}$ deep hole was made on trees of same girth class with the help of battery operated drill machine at $\mathrm{DBH}$ of tree.

\section{Mechanical + Chemical Tapping}

Nine chemical treatments were used for Boswellia serrata in both the season. The chemical gum tapping of selected trees was initiated using different doses of gum enhancer Ethephon (2-chloro-ethylphosphonic acid) (trade name Ethereal) having $39 \%$ a.i in $10 \%, 20 \%, 30 \%$ concentration were injected by syringe of 60 $\mathrm{ml}$ volume in the tree trunk to induce gummosis process.

The $4 \mathrm{ml}$ of gum enhancer Ethephon was injected on the tree trunk to tap the gum in selected all the tree by making Square shape, $\mathrm{V}$ shape and Hole shape cut made on trees.

The treatments are as follows: 


\section{Tapping technique}

Mechanical tapping technique

Mechanical + Chemical tapping technique

\section{Tapping season}

Winter (October-November), 2018

Summer (March-May), 2019

\section{Chemical concentration}

\begin{tabular}{|l|l|}
\hline Ethephon & a. $10 \%$ Concentration \\
\hline Ethephon & b. $20 \%$ Concentration \\
\hline Ethephon & c. $30 \%$ Concentration \\
\hline
\end{tabular}

In total 24 treatments $(6$ Mechanical treatment and 18 Mechanical+ Chemical treatment total in both the season) were applied on trees. Chemicals were sprayed through syringe with dose of $4 \mathrm{ml}$ per incision. Gum ooze out was collected an interval of 15 days during experimental period and weight of gum samples was taken with help of digital field weighing balance.

\section{Results and Discussion}

Season wise and Treatment wise gum exudation in Boswellia serata during winter 2018 and summer 2019 by various Methods used for this experiment (g/tree/season)

\section{Mechanical tapping technique}

In present investigation the highest rate of gum exudation and production was observed in mechanical method during summer season (March- May) i.e 10.82g in case of square shape cut and $6.53 \mathrm{~g}$ during winter season (October -December). Whereas, other two mechanical tapping method i.e. Hole shape and $\mathrm{V}$ shaped cut only in $\mathrm{V}$ shape method gum yield was $4.56 \mathrm{~g}$ recorded during summer season and Hole shape method did not showed much effective in sustainable production of gum. Square shape tapping method was found better during both the season in sustainable gum production. Bhatt et al., (1989) also reported in Commiphora wightii that April and May are the peak months for gum tapping.

The debarked area was scraped to freshen with iron Chisel at regular interval of 3-4 days. The maximum quantity of gum produced in square shape cut however, not a single drop of gum obtained in other shape of cuts in winter and summer season of 2018 and 2019. Ballal et al., (2005) also reported in his experiment that the Gum yield was positively correlated with tapping intensity, rainfall, and minimum and maximum temperature. The results obtained in the present experiment confirmed with the result of above worker that when the temperature is maximum and low relative humidity the rate of gum ooze out was more quantity. Similar finding also observed in this study confirms that the temperature and humidity playing a significant role in gum extraction method.

\section{Mechanical + chemical tapping technique}

In Boswellia serata highest winter and summer season total production of gum was obtained by using $\mathrm{H}_{4} 30 \%$ i.e. $52.94 \mathrm{gm}$ in summer season and lowest amount of gum obtained by using V4 30\% and the yield was 4.56 g. Similarly in winter season highest quantity of gum obtained was $26.18 \mathrm{~g}$ by using $\mathrm{V}_{3} \quad 20 \%$ and lowest quantity was obtained by using $\mathrm{S}_{2} 10 \%$ i.e. 2.08 g. Sinha et al., (2016) also reported that maximum gum yield obtained by $\mathrm{V}$ shaped cut method of 2 $\mathrm{cm}$ width for sustainable and high yield of gum in Boswellia serrata plantation.

Improved gum tapping method by using ethephon chemical treatment in tree trunk by injecting through a syringe into holes with the help of increment borer was developed and 
recommended by Bhatt (1987).The similar results were obtained in the present study that the gum exudation increases with the application of higher concentration of Ethephon i.e. $30 \%$ injected in tree trunk gave maximum yield as compared with the $10 \%$ confirms the results with the above worker. Babu and Menon (1989) also reported that Ethephon induces gummosis in Sterculia urens without adversely affecting health of the tree. The similar results obtained in the present study that use of ethephon does not affect the tree health and after the gum exudation incision portion was covered with wet mud to prevent from further infection. Due to this technique the bark growth easily covers the incision made on the tree trunk. The recovery of tissues and bark was recorded fast and filled the incision.Mishra et al., (2012) reported that there was no gum yield in trees of Boswellia serrata having $35 \mathrm{~cm}$ girth size. The small girth size of tree did not respond for good yield of gum.

The result on Season and Treatment wise gum exudation in Boswellia serata during winter 2018 and summer 2019 by using various shape Methods ( $\mathrm{g} /$ tree/season) presented in table 2 and figure 1, 2, 3, 4 and 5.

Month wise gum exudation rate in Boswellia serata during the year2018 -19 in winters and summer season (g/tree/month)

\section{Mechanical tapping technique}

In the present investigation maximum gum production rate was observed in mechanical method in May during summer i.e6.41 $\mathrm{g}$ and $2.39 \mathrm{~g}$ in October month winter season recorded in square shape incision. This result was found due to gum production is positively correlated with low relative humidity and high temperature. The average temperature during May and October was comparatively higher than other months so the gum yield was more in these two month. The debarked area was freshened with manual Chisel at regular interval of 3-4 days. The maximum quantity of gum produced in square shape however, not a single drop of gum produced in other shape of cuts in winter season.

The result on effect of mechanical tapping rate of gum exudation for the month of October to May both the seasons presented in (Table 3).

\section{Mechanical + chemical gum tapping technique}

The variation in gum exudation rate was recorded during October2018 to May 2019 both season's winter and summer. The highest rate of gum exudation was obtained in October month of winter season i.e. Maximum $14.32 \mathrm{~g} /$ tree/month in treatment $\mathrm{V} 320 \%$ conc. and in the month of May i.e. Maximum yield i.e. $30.15 \mathrm{~g} / \mathrm{tree} / \mathrm{month}$ was obtained treatment $\mathrm{H} 430 \%$ conc.. However, in mechanical and chemical method ethephon was used as gum enhancer. Bhatt et al., (1989) also reported that application of ethephon in gum yielding trees increases the amount of gum exudation and total yield of gum/tree. The Maximum average temperature goes high in May $2019\left(35.2^{\circ} \mathrm{C}\right)$ and $\mathrm{RH}$ was $(32.5 \%)$. During summer season month of May observed the best month showed significantly higher gum exudation followed by April and March. Ballal et al., (2005) also reported that the gum yield was positively correlated with tapping intensity, rainfall, and minimum and maximum temperatures at tapping time, and negatively correlated with tapping time, and minimum and maximum temperatures at gum collection. Sinha et al., (2016)also observed that $3 \mathrm{ml}$ ethephon (2chloroethylphosphonic acid) of 39\% solution; (l) $1.5 \mathrm{~cm}$ diameter hole treated with $3 \mathrm{ml}$ ethephon of 39\% solution and patched up with clay and the yield was $5.86 \pm 0.545$ in the month of May in Boswellia serata (5.86 \pm $0.545 \mathrm{~g} / \mathrm{incision} / \mathrm{plant})$ ). The results reported 
by the above workers are similar as in the month of May the gum exudation rate is high with the use of ethephon, however in present study the quantity of gum is more than 6 times high as reported by Sinha et al., (2016) observed in case of Boswellia serata it may be the GBH of the tree was $32-35 \mathrm{~cm}$ compared with the Boswellia serata the GBH was in the range of $80-150 \mathrm{~cm}$ this variation in quantity was recorded in our experiment the soil type and microclimate also responsible for the exudation rate of gum. The difference in tree species also responsible for the yield this hypothesis confirms the results obtained in the present study. The development of gum duct known as traumatic duct is responsible for the gummosis (Setia, 1984) and develops within the xylem tissue of the mature plants reported by various workers (Shah and Setia, 1976).

The result on effect of Mechanical + Chemical tapping technique and rate of gum exudation for the month of October to May both the seasons presented in Table 4.

\section{Quality parameter}

\section{Colour}

The gum colour in case of Boswellia serata was cream yellow in color. The similar colour also determined by visual observation of Boswellia serata was brownas reported by (Shirwaikar et.al. 2005). The results obtained in the experiment were almost same confirms the finding is correct and there is no difference or variation was recorded.

\section{Odour}

Odour of Boswellia serrata was noted as Sweet balsamic aromatic smell same observation was also reported by Gupta (2011) as well as (Shirwaikar et al., 2005) also confirm the result of aroma (Table 5).
pH

The $\mathrm{pH}$ value of Salai gum in the present experiment was 4.6. Chandola et.al (2011) also analyzes the phyto-chemical evaluation of Boswellia serrata and found that the $\mathrm{pH}$ was 6.09.The value of $\mathrm{pH}$ variation in case of Boswellia serrata was low value as compared by above author may be due to availability of salts in the soils, rainfall pattern and microclimate of Chhattisgarh. These factors are affecting the acidity of the gum obtained from tree.

\section{Moisture content}

The moisture content of Boswellia serrata was $17.32 \%$ recorded in our experiment as Gupta (2011) observed $20.74 \%$ there is $3.4 \%$ variation in moisture content may be because of soil moisture, acidity of soil and age of tree may be the reason of collected gum from the tree. The variation in moisture content is based on location specific character.

\section{Ash content}

The ash content of gum in Boswellia serrata was observed $1 \%$ as Shirwaikar et al., (2005) reported the ash content $1.75 \%$ this variation may be because of polysaccharide available in the gum sample differ in relation to the site and age of the tree. The results having significant variations in ash content of gum as per above worker since this is biological science such variation occurs because of many factors like site quality soil and microclimate.

\section{Statistical analysis}

The yield of gum showed statistically significant value $(\mathrm{P}<0.05)$ used with the chemical ethephon as compared to Mechanical Treatment because the ethephon act as a catalyst which activate the gummosis processes fast in the trees. Season was results 
also showed statistically significant value $(\mathrm{P}<0.05)$ the difference was due to high temperature and low relative $\mathrm{RH}$ and the maximum amount of obtained from the trees summer month of May, 2019.

In conclusions, the Salai gum obtained from the trees of Boswellia serrata is very important Indian gum yielding tree and having high economic value. Its demand is increasing day by day in western countries due to its industrial applications. However, its traditional extraction methods are unscientific and crude ones and cause severe injury to trees and ultimately population of trees are decreasing in alarming rate day by day. To overcome with this problem, proper gum tapping method known as $\mathrm{V}$ shape cut of length $9 \mathrm{~cm}$ and width $3 \mathrm{~cm}$ having depth of $1 \mathrm{~cm}$ depth given maximum yield from trees of $80-150 \mathrm{~cm}$ girth class and confined nearer to breast height with the help of chisel and gum inducer is injected with the help of syringe in lower portion incision. This technique is simple and safe ensure sustainable yield, regeneration and survival of the tapped trees without any kind of damage to the tree. The trees of Boswellia serrata by use of Mechanical + Chemical treatment Tapping technique total quantity of gum produced in two season in a year was highest in summer season by using $\mathrm{H}_{4} 30 \%$ conc. the yield was 52.94 gram/tree and in winter maximum gum was obtained by using V320\% conc. the yield was 26.18 gram/tree in winter season. Whereas, in Mechanical tapping techniques maximum gum was obtained by square shape cut method and the yield was 10.82gram/tree, the other two methods i.e. $\mathrm{V}$ shape and Hole shape not much effective for sustainable production of gum. The important conclusion of the study is that the Sustainable yield of gum, hole shape cut method along with Chemical ethephon i.e. (Mechanical + Chemical tapping technique) will be selected so that the gum tapping practices shall not affect the survival status of the species in the natural forest stands. Temperature and $\mathrm{RH}$ play a significant role in flow of gum through gum canals available in sap wood.

Table.1 Description of Boswellia serrata

\begin{tabular}{|l|l|}
\hline Botanical Classification & Vernacular names \\
\hline Division: Spermatophyta & $\begin{array}{l}\text { English: Indian Olibanum or Indian frankincense or } \\
\text { incese tree }\end{array}$ \\
\hline Sub-division: Angiospermae & Hindi: Kundur, Salai, \\
\hline Over-class: Rutanae & Chhattisgarhi- Salaiyya,Saale \\
\hline Class: Anacardiales & Odia-Salai \\
\hline Family: Burseraceae & Kannada: Chitta, Guguladhuph \\
\hline Genus: Boswellia & Gujarati: Dhup, Gugali \\
\hline Species: serrata & Telugu: Phirangi, Saambraani \\
\hline
\end{tabular}


Table.2 Season and Treatment wise gum exudation in Boswellia serata during winter 2018 and summer 2019 by using various shape Methods (gram/tree/season)

\begin{tabular}{|c|c|c|c|c|}
\hline SHAPE & MECHANICAL & $\begin{array}{l}\text { B. serrata g/tree } \\
\text { (Winter) }\end{array}$ & $\begin{array}{l}\text { B. serrata g/tree } \\
\text { (Summer) }\end{array}$ & $\begin{array}{l}\text { TOTAL } \\
\text { YIELD IN (g) }\end{array}$ \\
\hline \multirow[t]{5}{*}{ SQUARE SHAPE } & S1-0\% & $6.53 \mathrm{~g}$ & $10.82 \mathrm{gm}$ & 17.35 \\
\hline & MECHANICAL+CHEMICAL & & & \\
\hline & $\mathrm{S} 2-10 \%$ & $2.08 \mathrm{~g}$ & $35.18 \mathrm{~g}$ & 37.26 \\
\hline & S3-20\% & $17.21 \mathrm{~g}$ & 37.58g & 54.79 \\
\hline & $\mathrm{S} 4-30 \%$ & $7.57 \mathrm{~g}$ & $42.25 \mathrm{~g}$ & 49.82 \\
\hline \multirow[t]{6}{*}{ V SHAPE } & MECHANICAL & & & \\
\hline & $\mathrm{V} 1-0 \%$ & 0 gm & $4.56 \mathrm{~g}$ & 4.56 \\
\hline & MECHANICAL+CHEMICAL & & & \\
\hline & $\mathrm{V} 2-10 \%$ & $16.05 \mathrm{~g}$ & $23.57 \mathrm{~g}$ & 39.62 \\
\hline & $\mathrm{V} 3-20 \%$ & $26.18 \mathrm{~g}$ & $37.42 \mathrm{~g}$ & 63.6 \\
\hline & $\mathrm{V} 4-30 \%$ & $3.02 \mathrm{~g}$ & $6.48 \mathrm{~g}$ & 9.5 \\
\hline \multirow[t]{6}{*}{ HOLE SHAPE } & MECHANICAL & & & \\
\hline & H1-0\% & $\mathbf{0 g}$ & $\mathbf{0 g}$ & $\mathbf{0}$ \\
\hline & MECHANICAL+CHEMICAL & & & \\
\hline & H2-10\% & $13.93 \mathrm{~g}$ & $34.54 \mathrm{~g}$ & 48.47 \\
\hline & H3-20\% & $6.89 \mathrm{~g}$ & $41.15 \mathrm{~g}$ & 48.04 \\
\hline & H4-30\% & $5.34 \mathrm{~g}$ & $52.94 \mathrm{~g}$ & 58.28 \\
\hline
\end{tabular}


Table.3 Effect of temperature and relative humidity on rate of gum exudation in Boswellia serata by mechanical method (gram/month)

\begin{tabular}{|l|c|c|c|c|c|c|c|c|}
\hline Treatment & \multicolumn{3}{|c|}{ 2018(Winter) } & Total & \multicolumn{3}{c|}{ 2019(Summer) } & Total \\
\hline & Oct & Nov & Dec & & Mar & Apr & May & \\
\hline Temp $\left(^{\mathbf{0}} \mathbf{C}\right)$ & 27.10 & 23.65 & 19.15 & & 27 & 32.4 & 35.2 & \\
\hline Rh $(\%)$ & 66.50 & 60.00 & 65.00 & & 50.5 & 25.5 & 32.5 & \\
\hline T1 & 2.39 & 1.86 & 2.28 & 6.53 & 1.9 & 2.56 & 6.41 & 10.82 \\
\hline T2 & 0 & 0 & 0 & 0 & 0 & 2.22 & 2.34 & 4.56 \\
\hline T3 & 0 & 0 & 0 & 0 & 0 & 0 & 0 & 0 \\
\hline Total & $\mathbf{2 . 3 9}$ & $\mathbf{1 . 8 6}$ & $\mathbf{2 . 2 8}$ & $\mathbf{6 . 5 3}$ & $\mathbf{1 . 9}$ & $\mathbf{4 . 7 8}$ & $\mathbf{8 . 7 5}$ & $\mathbf{1 5 . 3 8}$ \\
\hline
\end{tabular}

T1-Square shape cut, T2-V Shape cut, T3-Hole shape cut

$$
\text { * } \mathrm{S}=\text { Square cut, } \mathrm{V}=\mathrm{V} \text { shape cut, } \mathrm{H}=\text { hole shape cut }
$$

Table.4 Effect of temperature and relative humidity on rate of gum exudation in Boswellia serata during summer and winter seasons 2018-2019 by using Various Mechanical+ Chemical Treatments (g/tree/month)

\begin{tabular}{|c|c|c|c|c|c|c|c|c|}
\hline \multirow[t]{2}{*}{ Treatment } & \multicolumn{3}{|c|}{ 2018(Winter) } & \multirow{2}{*}{$\begin{array}{l}\text { Total } \\
\text { yield }\end{array}$} & \multicolumn{3}{|c|}{ 2019(Summer) } & \multirow{2}{*}{$\begin{array}{l}\text { Total } \\
\text { yield }\end{array}$} \\
\hline & Oct & Nov & Dec & & Mar & Apr & May & \\
\hline $\operatorname{Temp}\left({ }^{0} \mathrm{C}\right)$ & 27.10 & 23.65 & 19.15 & & 27 & 32.4 & 35.2 & \\
\hline $\operatorname{Rh}(\%)$ & 66.5 & 60 & 65 & & 50.5 & 35.5 & 32.5 & \\
\hline T4 & 2.08 & $\mathbf{0}$ & $\mathbf{0}$ & 2.08 & 9.83 & 11.10 & 14.25 & 35.18 \\
\hline T5 & 10.12 & 3.54 & 2.39 & 16.05 & 3.20 & 8.72 & 11.65 & 23.57 \\
\hline T6 & 7.48 & 3.20 & 3.28 & 13.93 & 20.52 & 6.95 & 7.07 & 34.54 \\
\hline T7 & 9.52 & 4.26 & 3.43 & 17.21 & 7.30 & 9.83 & 20.45 & 37.58 \\
\hline T8 & 14.32 & 6.61 & 5.25 & 26.18 & 4.41 & 14.36 & 18.65 & 37.42 \\
\hline T9 & 4.39 & 2.48 & $\mathbf{0}$ & 6.89 & 6.41 & 14.28 & 20.46 & 41.15 \\
\hline T10 & 5.12 & 2.45 & $\mathbf{0}$ & 7.57 & 1.30 & 14.85 & 26.10 & 42.25 \\
\hline T11 & 3.02 & $\mathbf{0}$ & $\mathbf{0}$ & 3.02 & $\mathbf{0}$ & 3.16 & 3.42 & 6.48 \\
\hline T12 & 5.34 & $\mathbf{0}$ & $\mathbf{0}$ & 5.34 & 9.93 & 12.86 & 30.15 & 52.94 \\
\hline Total & 61.39 & 22.54 & 14.35 & 98.27 & 62.9 & 96.11 & 152.2 & 311.11 \\
\hline
\end{tabular}

T4-S210\% $\quad$ T7-S320\% $\quad$ T10-S430\%

T5-V210\% T8-V320\% T11-V430\%

T6-H210\% T9-H320\% T12-H430\%

$$
\begin{gathered}
\text { S = Square shape cut, } V=\text { V shape cut, } \\
\text { H= Hole shape cut. }
\end{gathered}
$$


Table.5 Quality parameter tests of Boswellia serrate GUM

\begin{tabular}{|l|l|}
\hline \multicolumn{1}{|c|}{ Parameters } & Boswellia Serrata \\
\hline 1. $\mathbf{p H}$ & 4.6 \\
\hline 2. Odour & Sweet balsamic aromatic \\
\hline 3. Colour & Cream yellow/white yellow \\
\hline 4. Moisture content & $17.32 \%$ \\
\hline 5. Ash Content & $1 \%$ \\
\hline
\end{tabular}
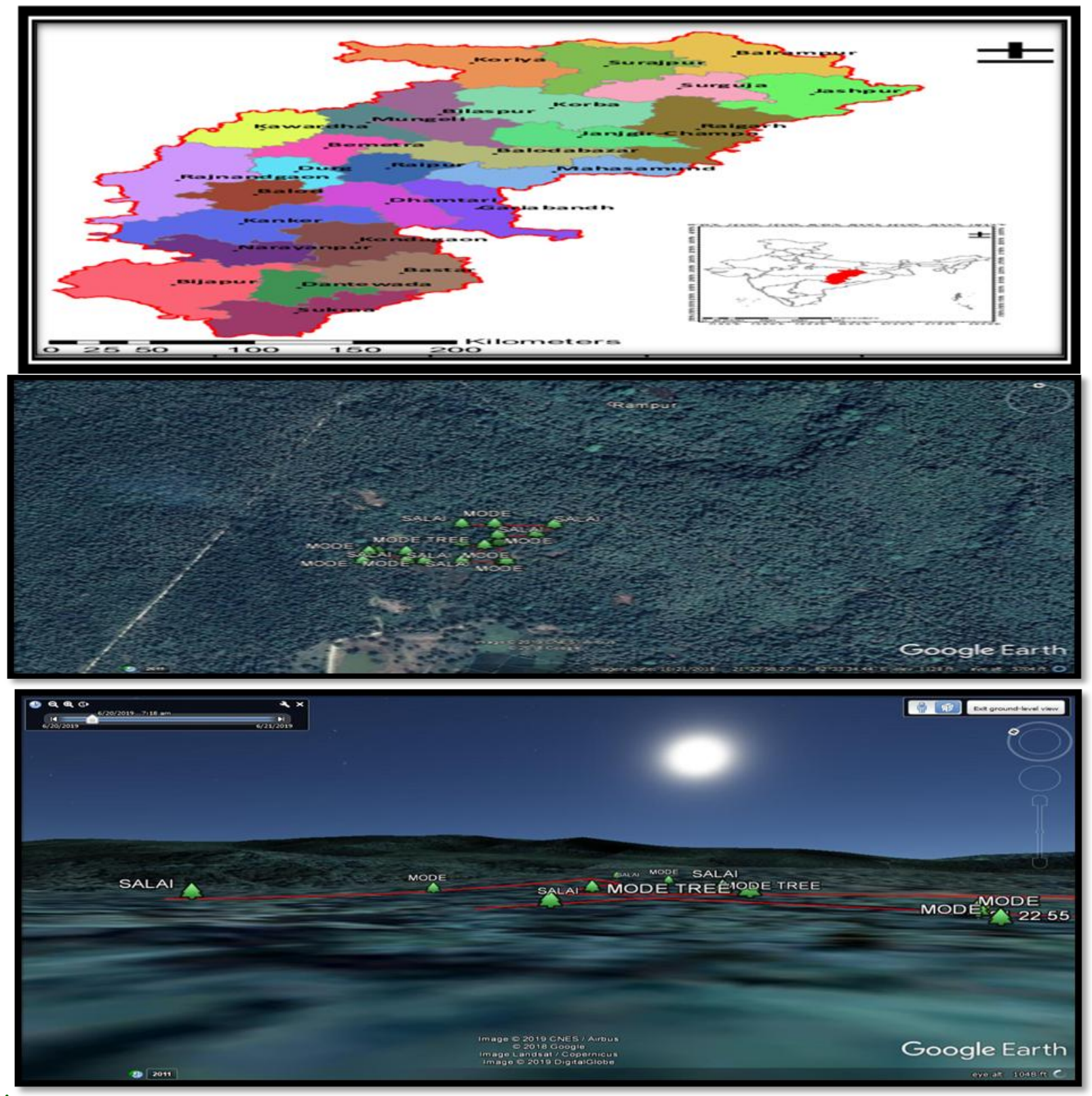

Plate.1 a) Map showing geographic location of Chhattisgarh state in India. b and c. Map showing geographic location of compartment no 281 of Deopur Forest Range in Balodabazar Forest Division, Chhattisgarh 


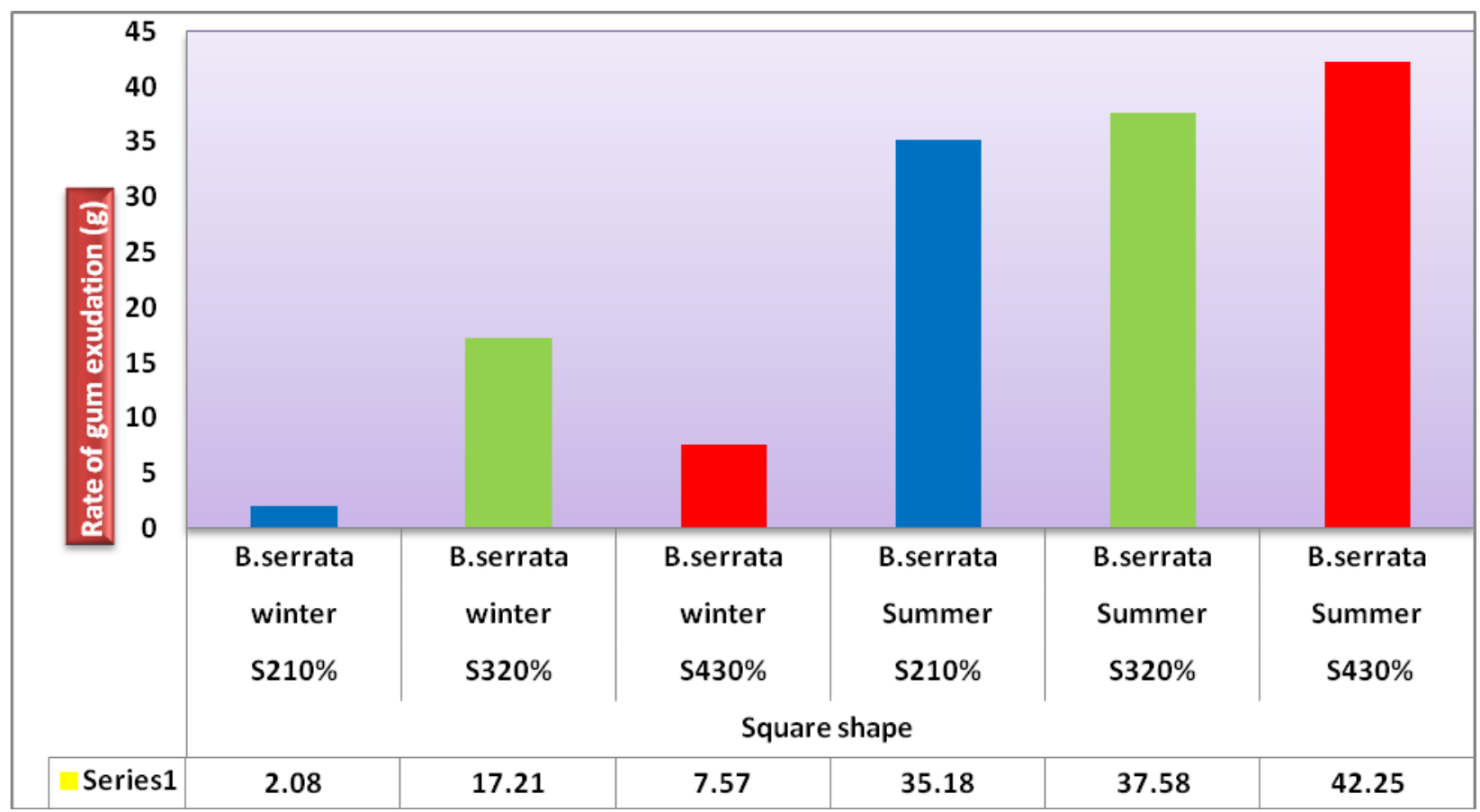

Figure.1 Gum exudation rate of Boswellia serata by Mechanical +Chemical tapping technique during winter 2018 and summer 2019 by Square shape cut Method (g/tree/season)

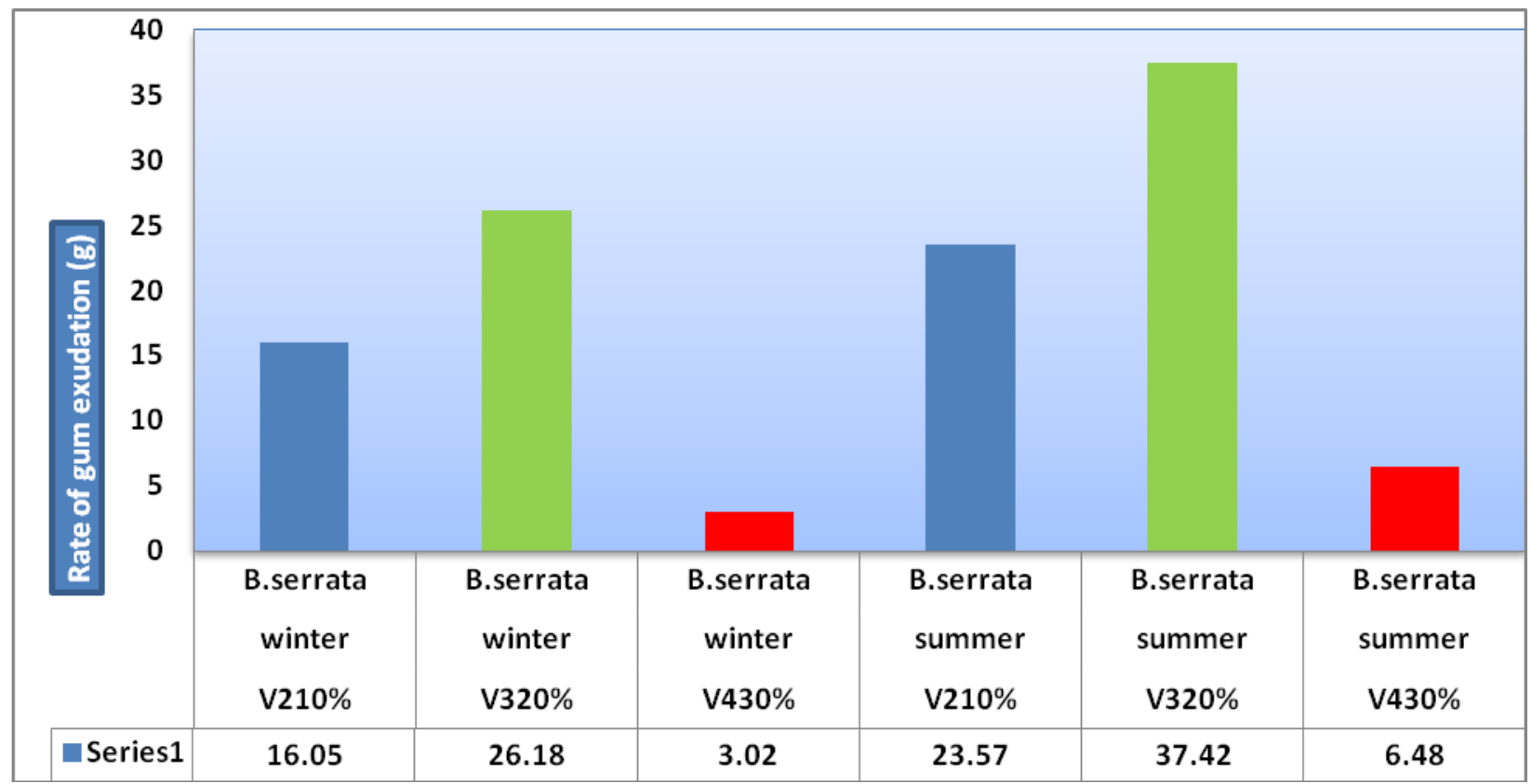

Figure.2 Gum exudation rate of Boswellia serata by Mechanical +Chemical tapping technique during winter 2018 and summer 2019 by V shape cut Method (g/tree/season). 


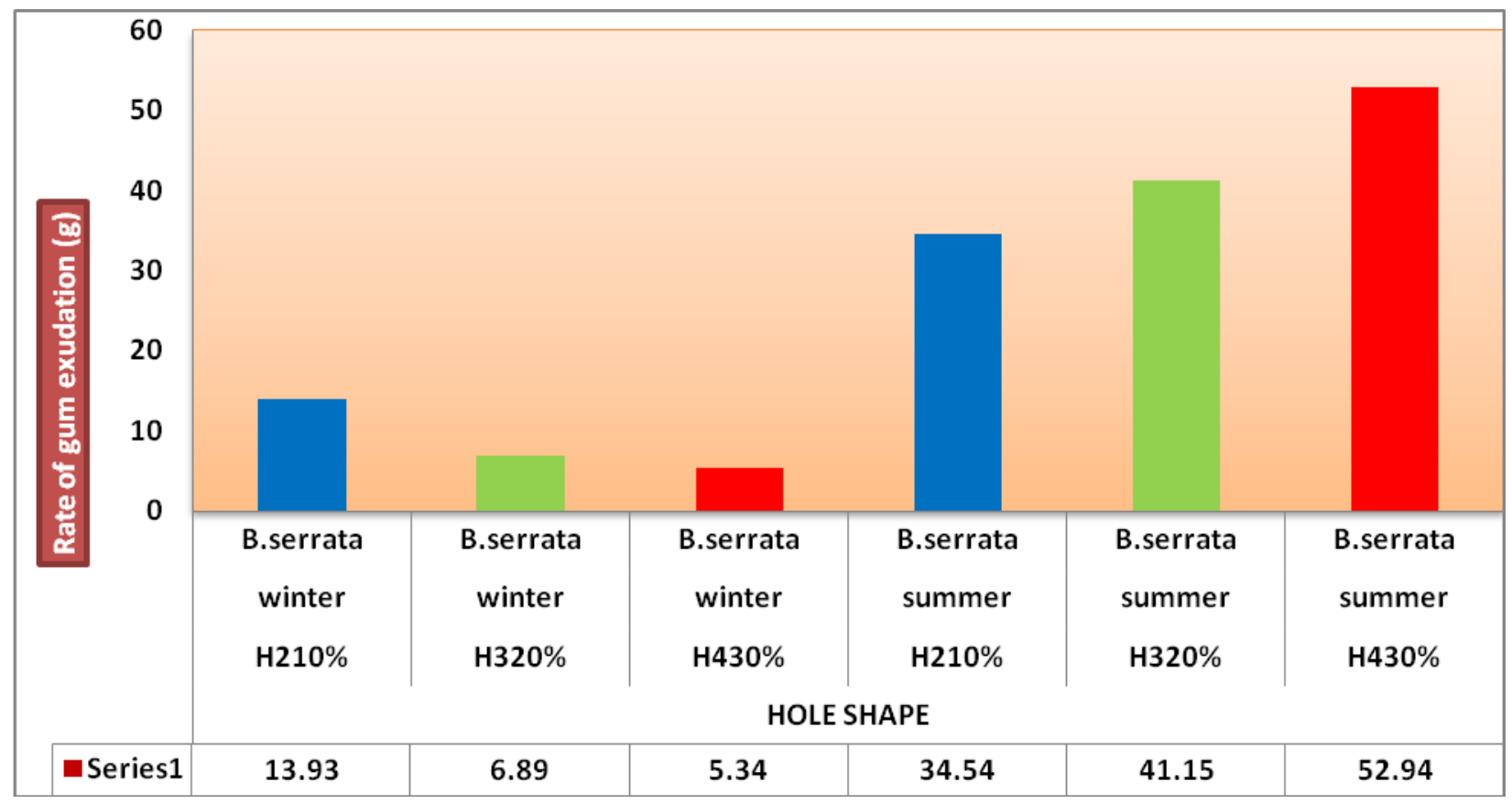

Figure.3 Gum exudation rate of Boswellia serataby Mechanical +Chemical tapping technique during winter 2018 and summer 2019 by Hole shape cut Method (g/tree/season)

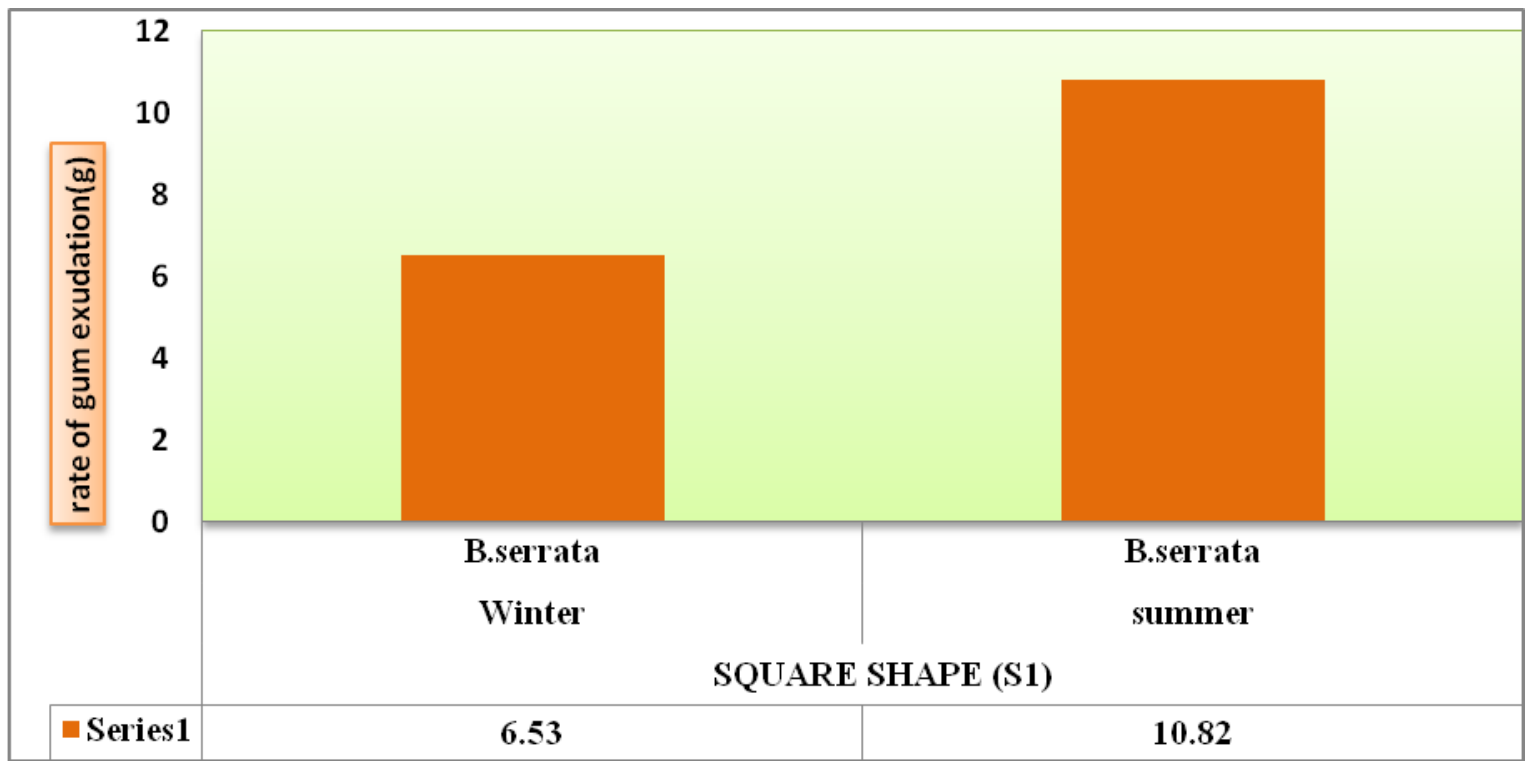

Figure.4 Comparison of Maximum oleo gum resin exudation rate with Season and Treatmentsin Mechanical tapping method. (Gram/tree/season) 


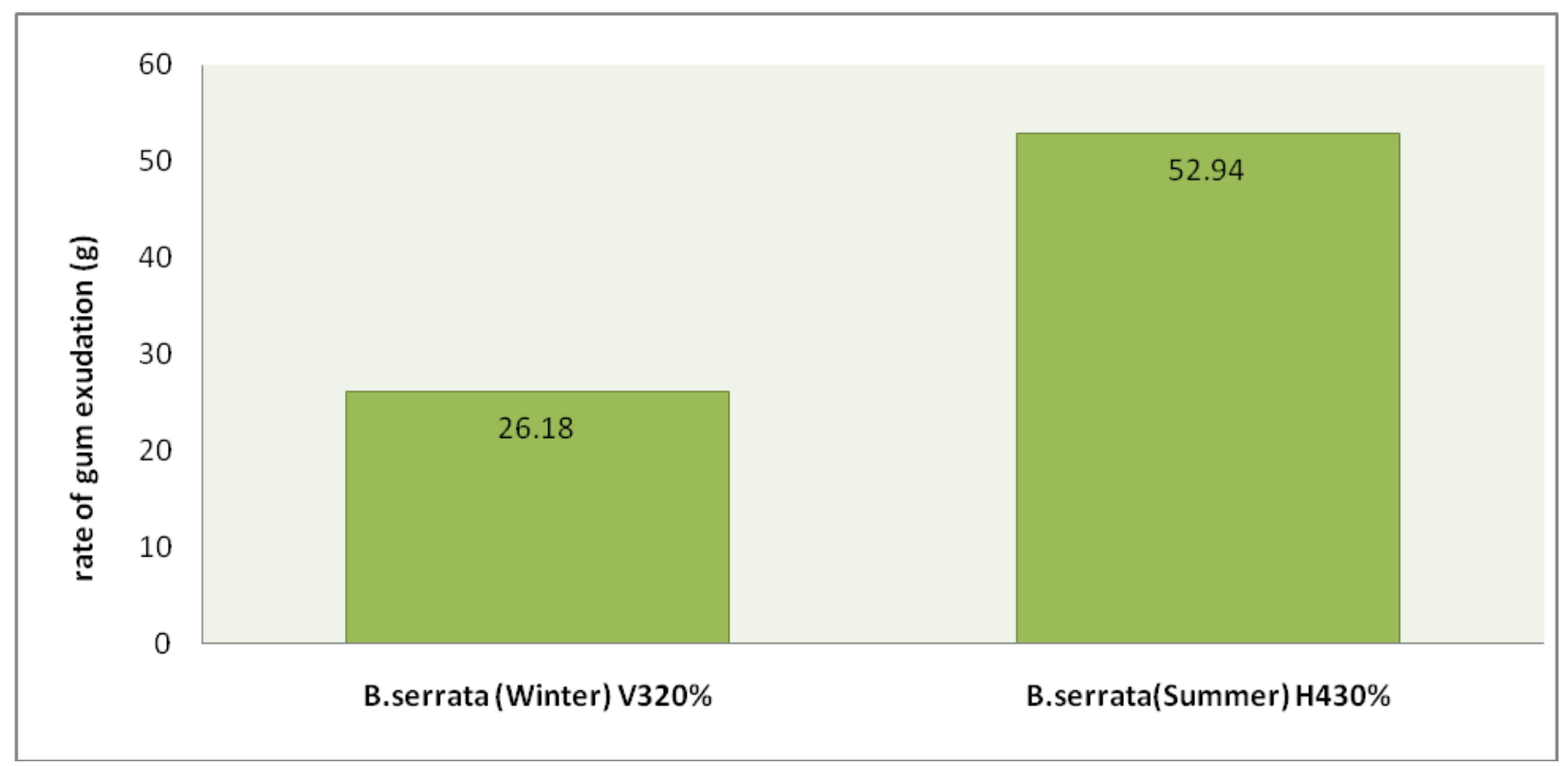

Figure.5 Comparison of maximum oleo gumresin exudation rate with Season and Treatments in Mechanical + Chemical tapping methods (Gram/tree/season)

- Winter (October-December)

- Summer (March-May)

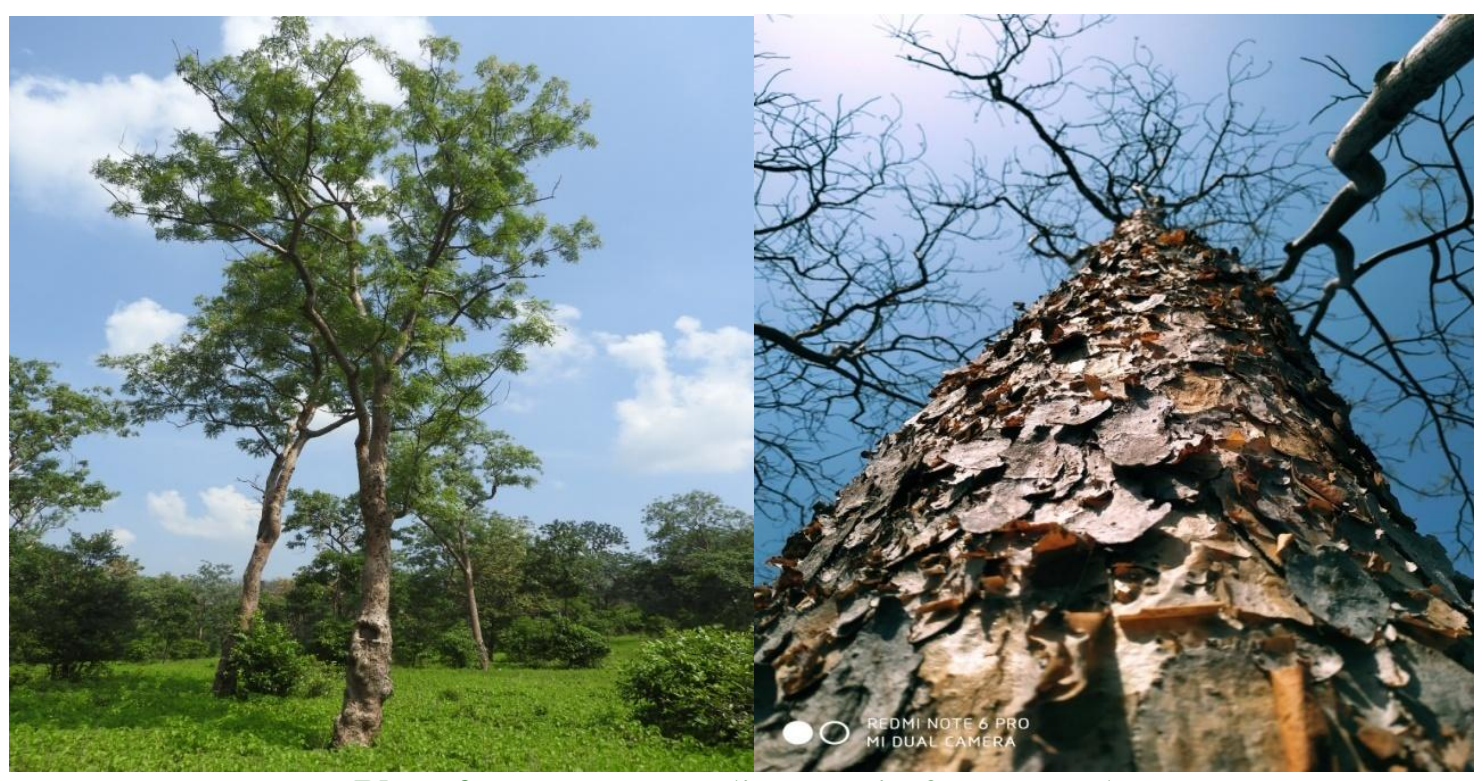

Plate.2 B.serrata standing tree in forest stands 


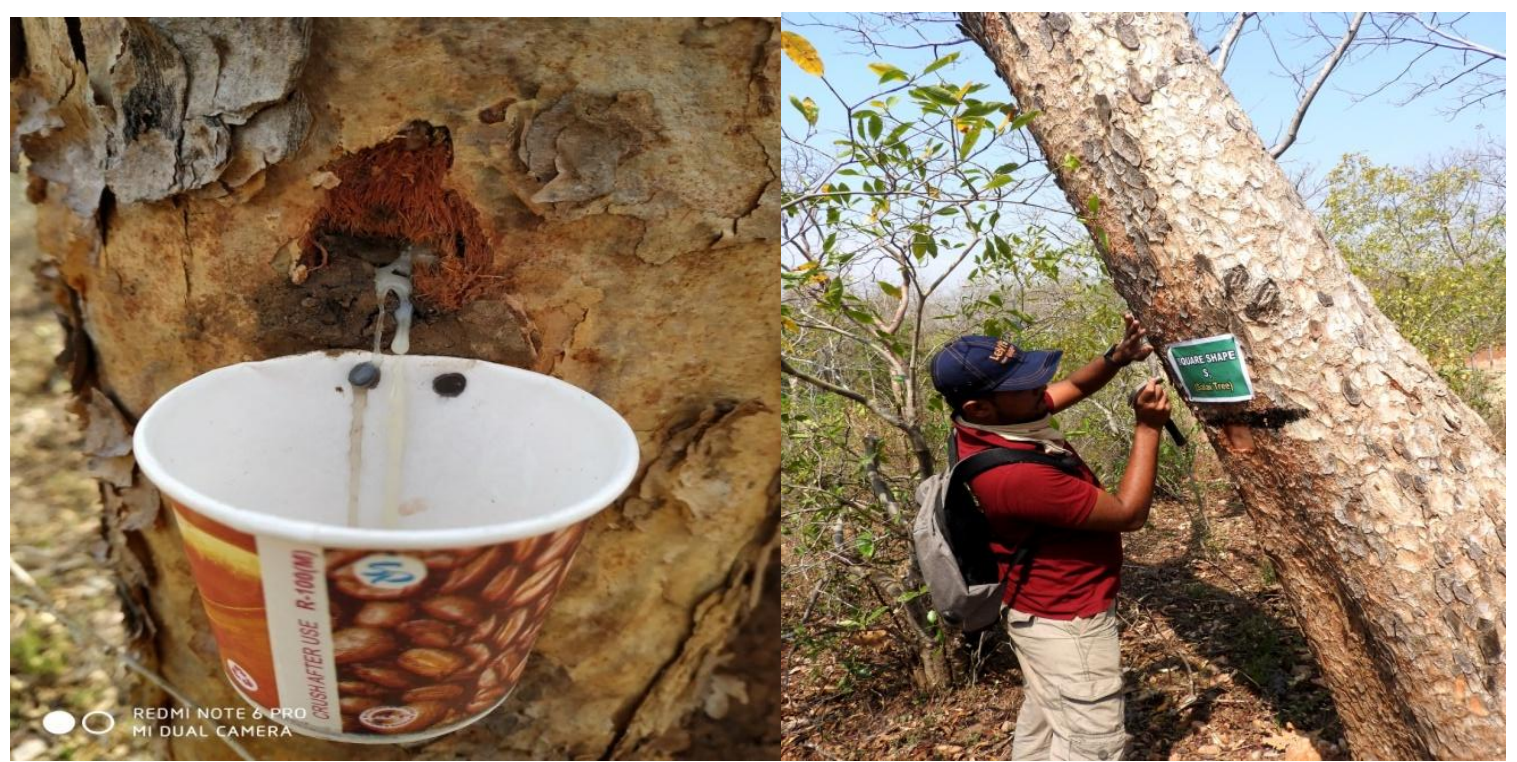

Plate.3 Gum exudation from B. serrate tree in hole shape cut Making incision in B.serrata tree

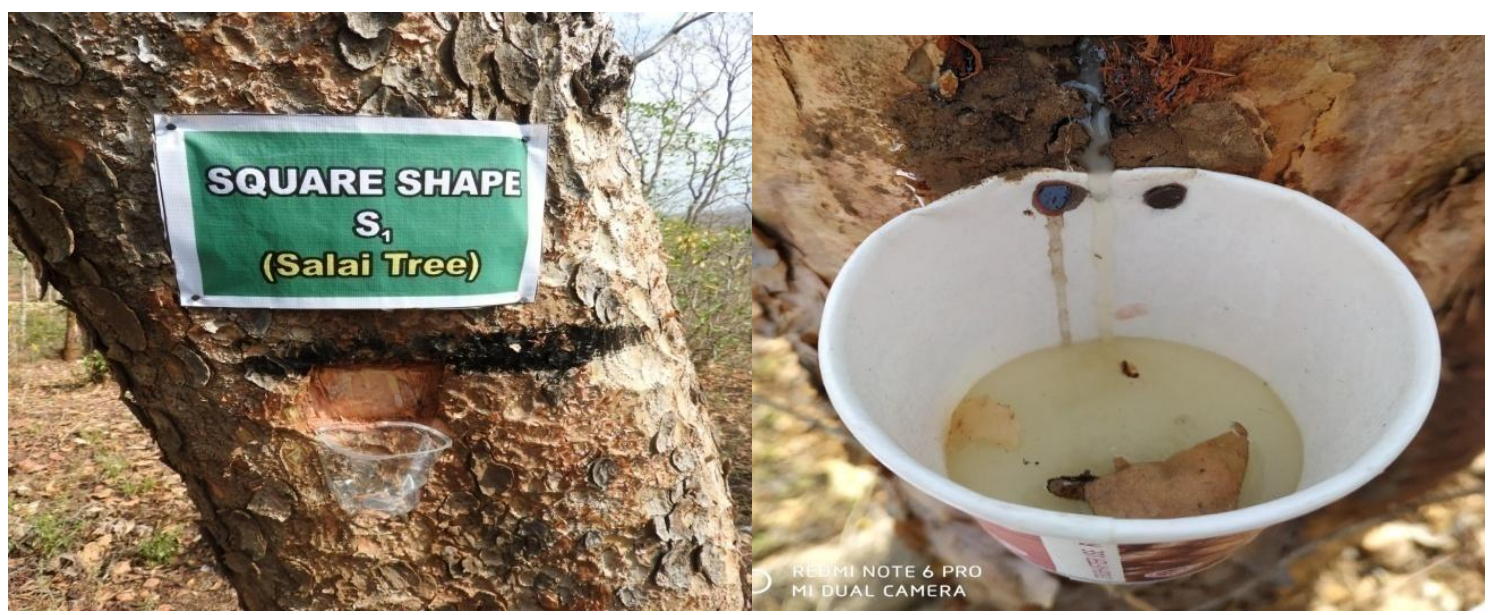

Plate.4 Square shape incision treatment on B.serrata tree White yellow colour of gum B.serrata

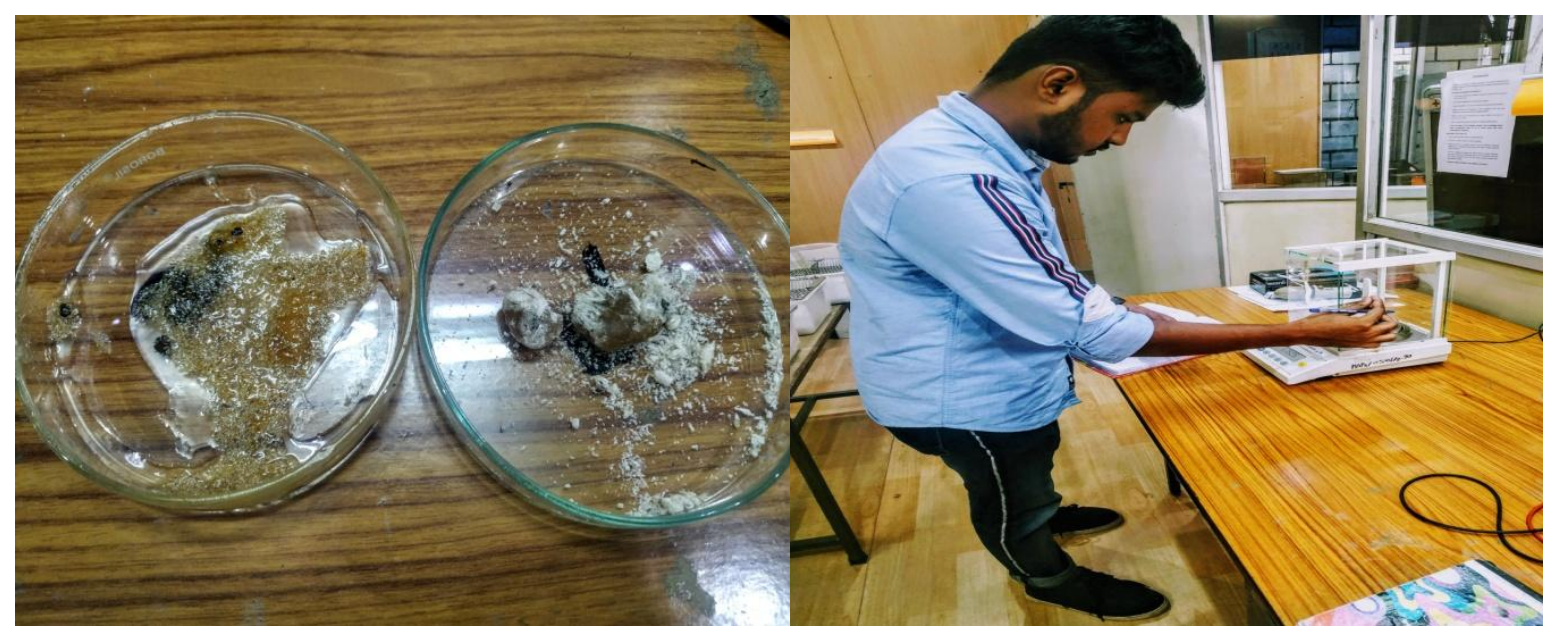

Plate.5 Quality parameter analysis from $B$ serrata sample 


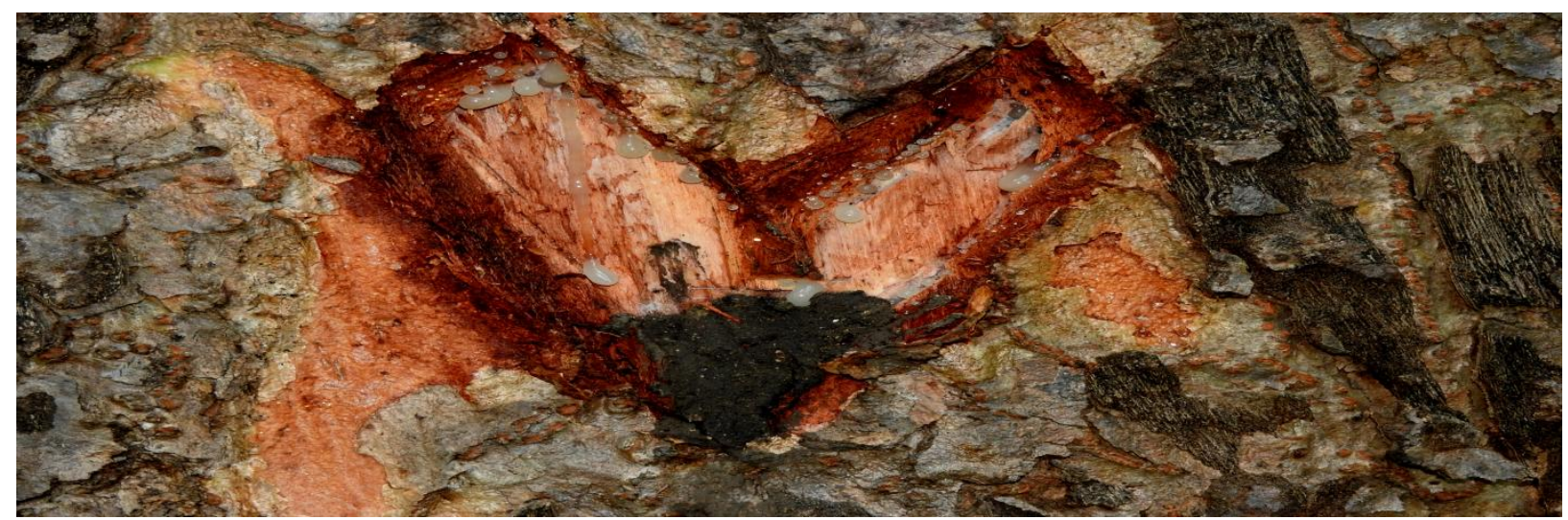

Plate-6: Gum exudation from V shape cut

\section{Acknowledgement}

The authors are highly thankful to Shri Vishwesh Roy (IFS), Divisional Forest Officer, Balodabazar and Bhatapara for providing the necessary facility needed to conduct the experiment in natural forest stands to undertake the present investigation during the study period.

\section{References}

Babu, A.M., and Menon, A.R.S. 1989. Ethephon induced gummosis in Bombax ceiba L. and Sterculia urens Roxb. Indian Forester, 115(1): 44-47

Ballala, M.E., Siddig., E.A., Elfadl ,M.A, Luukkanen., O. 2005. Relationship between environmental factors, tapping dates, tapping intensity and gum Arabic yield of an Acacia senegal plantation in western Sudan. Journal of Arid Environments, 63: 379-389.

Bhatt, J. R., Nair, M. N. B. and Mohan Ram, H. Y. 1989. Enhancement of oleo-gum resin production in Commiphora wightii by improved tapping technique, Current Science; Vol. 58(7): 349- 357.

Champion, H.G. and S.K. Seth. 1968. A Revised Survey of the Forest Type of India. Govt. of India Publications, New Delhi.
Chandola et al., 2011. Pharmacognostical and Phyto-Chemical evaluation of oleo gum- resin of Shallaki (Boswellia Serrata Roxb.). Journal of Pharmaceutical and Biomedical Sciences, Vol. 6 (16):1-5.

Gupta I., Parihar A., Malhotra P., Gupta S., Ludtke R., Safayhi H., Ammon H. P. 1997. Effects of Boswellia serrata gum resin in ulcerative colitis, Eur. J. Med. Res.; 2(1): 37-43.

Holmes P. Frankincense oil. Int J Arom., 1999; 9: 56-61.

MaheAlam, M., Khan, H., Samiullah, L and Siddique, K.M. 2012. A review on Phytochemical and Pharmacological studies of Kundur (Boswellia serrata Roxb ex Colebr.) -A Unani drug. Journal of Applied Pharmaceutical Science 02(03): 148-156.

Pharmacopoeia of India, Govt. of India, New Delhi: Ministry of Health and Family Welfare; 2007. Pp. 2045.

Setia, R. C. 1984. Traumatic Gum Duct Formation in Sterculia urensRoxb. In Response to injury, Phyton (Austria) 24: 253-255.

Shah, J. J. and Setia, R. C. 1976. Histological and Histochemical changes during the development of gum canals in Sterculia urens. Phytomorphology. 26: 151

Shirwaikar AA, Annie S, Aswatha R, Upadhyay, D.K. 2005. Formulation 
and Evaluation of Boswellia serrata tablet; Indian Journal of Pharmaceutical Sciences, 67(4): 427431.

Sinha, S. K., Pathak , J. G., Mehta, A. A. and L. K. Behera, L.K. 2016. Tapping Methods in Salaiguggal (Boswellia serrate Roxb.) for sustainable yield of oleo-gum resin: A case study. Int. J. of Usuf. Mngt. 17 (2): 13-18.

Thulin, M. and Warfa, A.M. 1987. The frankincense trees (Boswellia spp., Burseraceae) of northern Somalia and Southern Arabia. Kew Bulletin, 42 (3): 487-500.

\section{How to cite this article:}

Nayak Amit Prakash and Prajapati, R.K. 2020. Standardization of Sustainable Oleo Gum Resin Tapping Technique in Salai (Boswellia serrata Roxb.) from Tropical Dry Deciduous Forest of Chhattisgarh. Int.J.Curr.Microbiol.App.Sci. 9(10): 2281-2296.

doi: https://doi.org/10.20546/ijcmas.2020.910.276 